\title{
Isolation, Purification, and Characterization of a Polygalacturonase Produced in Penicillium solitum-Decayed 'Golden Delicious' Apple Fruit
}

\author{
Wayne M. Jurick, II, Ivana Vico, James L. McEvoy, Bruce D. Whitaker, Wojciech Janisiewicz, and William S. Conway
}

First, third, fourth, and sixth authors: Food Quality Laboratory, United States Department of Agriculture-Agricultural Research Service (USDA-ARS), BARC-West, Beltsville, MD; second author: Institute of Phytomedicine, Faculty of Agriculture, University of Belgrade, Serbia; and fifth author: Appalachian Fruit Research Station, USDA-ARS, Kearneysville, WV.

Accepted for publication 3 February 2009.

\begin{abstract}
Jurick, W. M., II, Vico, I., McEvoy, J. L., Whitaker, B. D., Janisiewicz, W., and Conway, W. S. 2009. Isolation, purification, and characterization of a polygalacturonase produced in Penicillium solitum-decayed 'Golden Delicious' apple fruit. Phytopathology 99:636-641.

Polygalacturonase (PG) was extracted and purified from decayed 'Golden Delicious' apple fruit inoculated with Penicillium solitum. Ammonium sulfate, gel filtration, and cation exchange chromatography were used to purify the enzyme. Both chromatographic methods revealed a single peak corresponding to PG activity. The purified PG most likely originates from the fungus because PG activity from healthy and wounded apple tissue was undetectable. Analysis of cation exchangepurified material using sodium dodecyl sulfate polyacrylamide gel
\end{abstract}

ABSTRACT electrophoresis revealed a single $50-\mathrm{kDa}$ band. The enzyme was active over a broad $\mathrm{pH}$ range ( 3 to 7 ), with optimal activity between $\mathrm{pH} 4$ and 5 . PG was highly active at 20 and $37^{\circ} \mathrm{C}$ but was also detectable at 2,50 , and $75^{\circ} \mathrm{C}$. Divalent cations affected PG enzyme activity; $\mathrm{Mg}$ and $\mathrm{Fe}$ increased, whereas $\mathrm{Ca}$ and $\mathrm{Mn}$ reduced activity in vitro. Thin-layer chromatographic separation of hydrolysis products and data from a PG plate activity assay based on staining with ruthenium red showed that the enzyme exhibits both exo and endo activity. Purified PG incubated with intact apple fruit tissue in vitro caused a 30\% reduction in mass after $48 \mathrm{~h}$, suggesting a role in $P$. solitum-mediated decay of apple fruit.

Additional keywords: maceration, postharvest decay.
Penicillium solitum Westling is a necrotrophic fungal plant pathogen that infects apple and pear fruit, primarily through wounds in storage. A closely related Penicillium sp., P. expansum, has been shown to be more aggressive than $P$. solitum $(18,22)$. However, both pathogens are capable of causing significant economic postharvest losses (27). Investigation of decay incidence caused by Penicillium spp. of apple and pear showed that $P$. solitum was the most frequently isolated $(145 / 322=45 \%)$ compared with the other Penicillium spp. collected in Victoria, Australia and was differentiated based on pectic zymograms (22). P. solitum has also been isolated from processed meats, cheeses, rye bread, and cereals and produces copious amounts of dark-bluish-green conidia in culture and on the surface of infected fruit $(22,33)$. It also exhibits a brownish orange reverse in culture, which has been structurally characterized and identified as solistatin (33). Solistatin belongs to a class of polyketide-derived compounds known as compactins, which have been widely used in medicine for their cholesterol-lowering ability in humans (15). However, the role of solitstatin in the $P$. solitum-apple fruit interaction has not been examined.

The plant cell wall serves as the major physiochemical barrier to the establishment of plant pathogens (34). It contains an abundance of carbon and nitrogen in the form of polysaccharides and proteins that can be broken down into their assimilable forms via cell-wall-degrading enzymes (CWDEs), including pectinases, proteases, and cellulases. Polygalacturonases (PGs) (EC 3.2.1.15)

Corresponding author: W. M. Jurick, II; E-mail address: Wayne.Jurick@ars.usda.gov

doi:10.1094/PHYTO-99-6-0636

This article is in the public domain and not copyrightable. It may be freely reprinted with customary crediting of the source. The American Phytopathological Society, 2009. are produced by bacterial and fungal parasites to facilitate the invasion and colonization of host tissue. They are detectable in the initial stages of plant infection and produced in copious amounts during host colonization (10). PGs have been associated with diseases characterized by tissue maceration and soft rot $(3,4)$. Conclusive evidence that PG contributes significantly to virulence was achieved via analyses of mutants lacking PGs $(11,30)$. PGs are also produced by plants and, in apple, have been shown to be involved in fruit ripening and softening via degradation of apple cortical cell walls $(2,37)$.

Pectin is found in the middle lamella of primary cell walls of dicots and nongraminaceous monocots. It is complexed with hemicellulose, provides cell wall integrity, is a critical component for plant tissue organization, and adds texture to fruit and vegetables (21). Pectin is composed of polymers of D-galacturonic acid linked by $\alpha-1,4$-glycosidic bonds, which are crosslinked by carboxyl groups with divalent cations such as $\mathrm{Ca}$ and $\mathrm{Mg}$ (12). Pectin lyases are another major class of hydrolases responsible for pectin breakdown and have been isolated from bacteria and fungi associated with soft rot and food spoilage (13). Carboxyl groups of polygalacturonic acid can be methyl esterified, which alters the degree of cross-linking between polypectate chains (12). PG enzyme action can be classified as endo- and or exo-activity, depending on the location of enzyme cleavage within the substrate $(1,10)$. In this reaction, the $\alpha-1,4$-glycosidic bond between adjacent polygalacturonic acid residues is hydrolyzed by a single displacement mechanism (20).

PG has been shown to play a significant role in tissue maceration, colonization, and virulence in diverse pathosystems. However, it is not clear whether reduced aggressiveness of $P$. solitum compared with $P$. expansum during host invasion and colonization results from a less efficient or "inferior" $\mathrm{PG}$ produced by this 
pathogen. Therefore, the objectives of this study were to (i) isolate and purify PG from $P$. solitum-decayed apple fruit, (ii) biochemically characterize the purified PG, and (iii) investigate whether or not the purified enzyme was capable of macerating apple fruit tissue in vitro. Data from this study have demonstrated for the first time that PG produced by $P$. solitum in decayed apple fruit can function over broad $\mathrm{pH}$ and temperature ranges, has a limited level of thermostability compared with $\mathrm{PG}$ from $P$. expansum, and can macerate apple fruit tissue in vitro. Results of this study provide a foundation for investigating the biological role of PG at the molecular genetic level in this pathogen.

\section{MATERIALS AND METHODS}

Fruit, pathogen and chemicals. Mature 'Golden Delicious' apple fruit were harvested from a commercial orchard in Pennsylvania in 2007. P. solitum was isolated from naturally infected apple fruit (kindly supplied by Dr. Robert Spotts at Oregon State University) and maintained on potato dextrose agar. All chemicals used in this work were purchased from Sigma-Aldrich (St. Louis) unless indicated otherwise.

Fruit inoculation and PG extraction. Apple fruit were subjected to the following treatments: wound inoculation with $50 \mu \mathrm{l}$ of conidial spore suspension of $P$. solitum $\left(10^{5}\right.$ conidia $\left./ \mathrm{ml}\right)$ as previously described (7), wound inoculation with $50 \mu \mathrm{l}$ of sterile water; and placing $50 \mu \mathrm{l}$ of sterile water on the surface of unwounded healthy apple fruit. After 14 days at $24^{\circ} \mathrm{C}$, the peel over the lesion was removed and the decayed cortical tissue was collected for enzyme extraction. Decayed tissue was weighed and an equal amount of tissue was also harvested from the healthy and wounded apple fruit. The fruit tissue was added to an equal volume of $20 \mathrm{mM}$ 2-[N-morpholino] ethanesulfonic acid (MES) with $1 \mathrm{M}$ sodium chloride, $\mathrm{pH}$ 6.0, and stirred for $30 \mathrm{~min}$, followed by filtering through Miracloth (Calbiochem-Behring, La Jolla, CA). The filtrates from each sample (decayed, healthy, and wounded) were centrifuged at $20,000 \times g$ for $30 \mathrm{~min}$ and ammonium sulfate was added to the supernatant to $40 \%$ saturation while stirring. Once the ammonium sulfate dissolved, the mixtures were centrifuged for $30 \mathrm{~min}$ at $20,000 \times \mathrm{g}$. Ammonium sulfate was added to the supernatants to obtain $90 \%$ saturation. These mixtures were then centrifuged for $30 \mathrm{~min}$ at $20,000 \times g$ and the supernatants were discarded. The pellets were dissolved in $20 \mathrm{mM}$ MES with $0.15 \mathrm{M}$ sodium chloride ( $\mathrm{pH}$ 6.0) and stored at $4^{\circ} \mathrm{C}$. All extraction and purification procedures were carried out at $4^{\circ} \mathrm{C}$.

PG purification. Approximately $5 \mathrm{ml}$ of the dissolved $90 \%$ ammonium sulfate pellet was loaded onto a Sephacryl S-200 column $(2.5$ by $52 \mathrm{~cm})$ that was equilibrated with $20 \mathrm{mM}$ MES in $0.15 \mathrm{M}$ sodium chloride ( $\mathrm{pH}$ 6.0). PG was eluted using the above buffer at $30 \mathrm{ml} / \mathrm{h}$ and $604-\mathrm{ml}$ fractions were collected. Following elution, gel filtration fractions from decayed tissue exhibiting PG activity were pooled and dialyzed overnight against $20 \mathrm{mM}$ MES (pH 6.0). PG was further fractionated on a CM-Sephadex column (Pharmacia C-25 cation exchange) equilibrated with $20 \mathrm{mM}$ MES, pH 6.0. The solution was placed on the column $(1.6 \times$ $9.8 \mathrm{~cm}$ ) and washed with $20 \mathrm{mM}$ MES, pH 6.0. PG was eluted with a linear gradient $(30 \mathrm{ml} / \mathrm{h})$ of $20 \mathrm{mM}$ MES to $20 \mathrm{mM}$ MES with $700 \mathrm{mM} \mathrm{NaCl}$ (pH 6.0) and collected in 30 4-ml fractions.

PG enzyme assay. PG activity was determined by measuring reducing sugars released from sodium polypectate, using D-galacturonic acid as the standard (38). An aliquot of the enzyme preparation was mixed with $0.1 \mathrm{ml}$ of standard assay buffer (100 mM sodium acetate, $\mathrm{pH} 5.5$, containing $0.4 \%$ polygalacturonic acid) and adjusted to a final volume of $0.2 \mathrm{ml}$ with water in $13 \times 100$-mm borosilicate tubes. This mixture was incubated at $37^{\circ} \mathrm{C}$ for $2 \mathrm{~h}$ and $1 \mathrm{ml}$ of $100 \mathrm{mM}$ borate-borax buffer (pH 9.0) was added to stop the reaction. A $0.2-\mathrm{ml}$ solution of $0.1 \%$ 2-cyanoacetamide was added and samples were placed into a boiling water bath for $10 \mathrm{~min}$. Samples were then equilibrated to $20^{\circ} \mathrm{C}$ and absorbance at $276 \mathrm{~nm}$ was measured. Control reactions were carried out by adding borate-borax buffer with 2-cyanoacetamide prior to the addition of substrate buffer, and were run with each sample to determine background levels of reducing sugars. One unit of PG activity was defined as the amount of enzyme required to release 1 nanomole of reducing sugar per minute per milliliter under the assay conditions employed.

PG plate activity assay. PG activity was determined by a modified method previously described (28). A $1 \%$ (wt/vol) agarose solution was heated in a microwave until dissolved. A $0.1 \%$ solution of sodium polypectate was added to the agarose solution and adjusted to $\mathrm{pH} 5.5$ with $1 \mathrm{~N} \mathrm{NaOH}$ solution while stirring. Then, $25 \mathrm{ml}$ of the agarose solution was poured into $100 \times 15-\mathrm{mm}$ petri dishes and allowed to cool. Four wells were punched in the agarose using a cork borer ( $2 \mathrm{~mm}$ in diameter) and solutions were pipetted into each of the wells. The plates were incubated at $37^{\circ} \mathrm{C}$ for $30 \mathrm{~min}$ before staining with $0.05 \%$ (wt/vol) ruthenium red (Acros) for $30 \mathrm{~min}$ at $20^{\circ} \mathrm{C}$. Plates were destained with deionized water for $30 \mathrm{~min}$ and visualized on a light box.

Effect of divalent cations on PG activity. The effects of divalent cations on PG activity were determined by adding $\mathrm{CaCl}_{2}$, $\mathrm{MgCl}_{2}, \mathrm{MnSO}_{4}$, and $\mathrm{FeCl}_{2}$ at a $1 \mathrm{mM}$ final concentration to the standard PG activity assay reaction. Reactions were conducted in duplicate and the experiment was repeated. The activity measured in the absence of cations was recorded as $100 \%$.

Effect of temperature on PG enzyme activity. The effect of temperature on PG enzyme activity was carried out by incubating purified PG in water baths set at 2,20,37, 50, and $75^{\circ} \mathrm{C}$ for $2 \mathrm{~h}$ in $13 \times 100-\mathrm{mm}$ borosilicate tubes. Heat stability of the $P$. solitum PG was assessed by incubating purified PG in a boiling $\left(100^{\circ} \mathrm{C}\right)$ water bath for $0,5,10,15,20,25$, and $30 \mathrm{~s}$ as previously described (38). PG activity was determined by detection of reducing sugars as carried out in the standard PG activity assay described earlier. Assays for each temperature and duration were conducted in triplicate and both experiments were repeated.

Effect of pH on PG activity. To determine the optimal $\mathrm{pH}$ for PG activity, assays were performed in $100 \mathrm{mM}$ sodium acetate buffer with $0.4 \%$ polygalacturonic acid adjusted to a $\mathrm{pH}$ of 3.0 to 7.0 in $0.5 \mathrm{pH}$ increments as described previously $(38,39)$. Reactions were conducted in triplicate and the experiment was repeated.

Protein assay and sodium dodecyl sulfate polyacrylamide gel electrophoresis. Estimation of the purified PG protein was accomplished by using the micro-BCA protein assay kit (Pierce, Rockford, IL), based on the method described by Smith et al. (32). A standard curve was constructed using known amounts of bovine serum albumin. Sodium dodecyl sulfate polyacrylamide gel electrophoresis (SDS-PAGE) of proteins was performed in a Bio-Rad Mini-protean III cell using a precast 4 to $20 \%$ gradient gel according to Leammli (16). The molecular mass of the protein was estimated using Protein Plus Precision Standards from BioRad Laboratories (Hercules, CA). Protein bands were visualized using the SilverQuest staining kit (Invitrogen, Carlsbad, CA) according to the instructions provided.

Thin-layer chromatography analysis of PG products. The reaction mixture for thin-layer chromatography (TLC) analysis consisted of $475 \mu \mathrm{l}$ of $100 \mathrm{mM}$ sodium acetate, $\mathrm{pH} 5.5$, with or without an ethanol-washed polygalacturonic acid substrate, plus $25 \mu \mathrm{l}$ of cation-exchange-purified PG $(0.136 \mathrm{U})$ in $20 \mathrm{mM}$ MES, $\mathrm{pH}$ 6.0. After incubation for $2 \mathrm{~h}$ at $37^{\circ} \mathrm{C}$, all samples were passed through Microcon centrifugal filter devices (prerinsed with $500 \mu \mathrm{l}$ of water to remove trace amounts of glycerol) with a $10-\mathrm{kDa}$ cutoff cellulose acetate membrane (Millipore Corporation, Bedford, MA) for $30 \mathrm{~min}$ at $20^{\circ} \mathrm{C}$ in a microcentrifuge at $14,000 \mathrm{rpm}$. Sample filtrates $(\approx 450 \mu \mathrm{l})$ were transferred to 2 -ml glass screwcap vials. Each microfuge tube was rinsed with $0.5 \mathrm{ml}$ of $80 \%$ ethanol, which was combined with the corresponding filtrate. Sample volumes were reduced to $\approx 0.2 \mathrm{ml}$ by nitrogen evaporation 
at $50^{\circ} \mathrm{C}$. This was followed by the addition of another $0.5 \mathrm{ml}$ of $80 \%$ ethanol and nitrogen evaporation to dryness. The filtrate residue was suspended in $100 \mu \mathrm{l}$ of $80 \%$ ethanol, and the vials were capped and vortexed for $30 \mathrm{~s}$ and centrifuged at 2,000 $\times g$ for $2 \mathrm{~min}$. The ethanolic solution was transferred to a microfuge tube and spun at $16,000 \times g$ for $90 \mathrm{~s}$ prior to application to a $10 \times 20$-cm glass TLC plate precoated with $250-\mu \mathrm{m}$-thick silica gel 60 (EM Science, Darmstadt, Germany). Samples from the reactions and standards (mono-, di-, and trigalacturonic acid at $1 \mathrm{mg} / \mathrm{ml}$ in $80 \%$ ethanol) were applied in 1-cm-wide bands, using a stream of nitrogen to evaporate the solvent. Each sample $(30 \mu \mathrm{l}$ of $100 \mu$ total) was used, including (i) enzyme with no substrate, (ii) substrate in buffer without enzyme, (iii) substrate with enzyme, (iv) digalacturonic acid plus enzyme, and (v) trigalacuturonic acid with enzyme. Aliquots $(5 \mu \mathrm{g})$ of the three standards (mono-, di-, and trigalacturonic acid) were applied individually to three lanes, and $5 \mu \mathrm{l}$ of each standard was combined in a fourth lane. The TLC plate was developed in the ethyl acetate:acetic acid:formic acid:water (9:3:1:4, vol/vol/ $/ \mathrm{vol} / \mathrm{vol})$ solvent system. After development, the plate was air dried in a fume hood for $12 \mathrm{~h}$ and sprayed with orcinol reagent $(0.2 \%$ orcinol [wt/vol] in

TABLE 1. Extraction and purification of polygalacturonase from 'Golden Delicious' apple cortical tissue decayed by Penicillium solitum

\begin{tabular}{lcccc}
\hline Purification step & $\begin{array}{c}\text { Protein } \\
(\mathrm{mg} / \mathrm{ml})\end{array}$ & $\begin{array}{c}\text { Total activity } \\
(\mathrm{U} / \mathrm{min} / \mathrm{ml})\end{array}$ & $\begin{array}{c}\text { Specific activity } \\
(\mathrm{U} / \mathrm{mg})\end{array}$ & $\begin{array}{c}\text { Yield } \\
(\%)\end{array}$ \\
\hline Crude extract & 7.7 & 245.7 & 31.9 & 100 \\
90\% $\left(\mathrm{NH}_{4}\right)_{2} \mathrm{SO}_{4}$ pellet & 1.20 & 58.4 & 48.6 & 23.7 \\
Sephacryl S-200 & 0.294 & 25.6 & 87.0 & 10.4 \\
CM-Sephadex C-25 & 0.139 & 14.2 & 102.1 & 5.77 \\
\hline
\end{tabular}
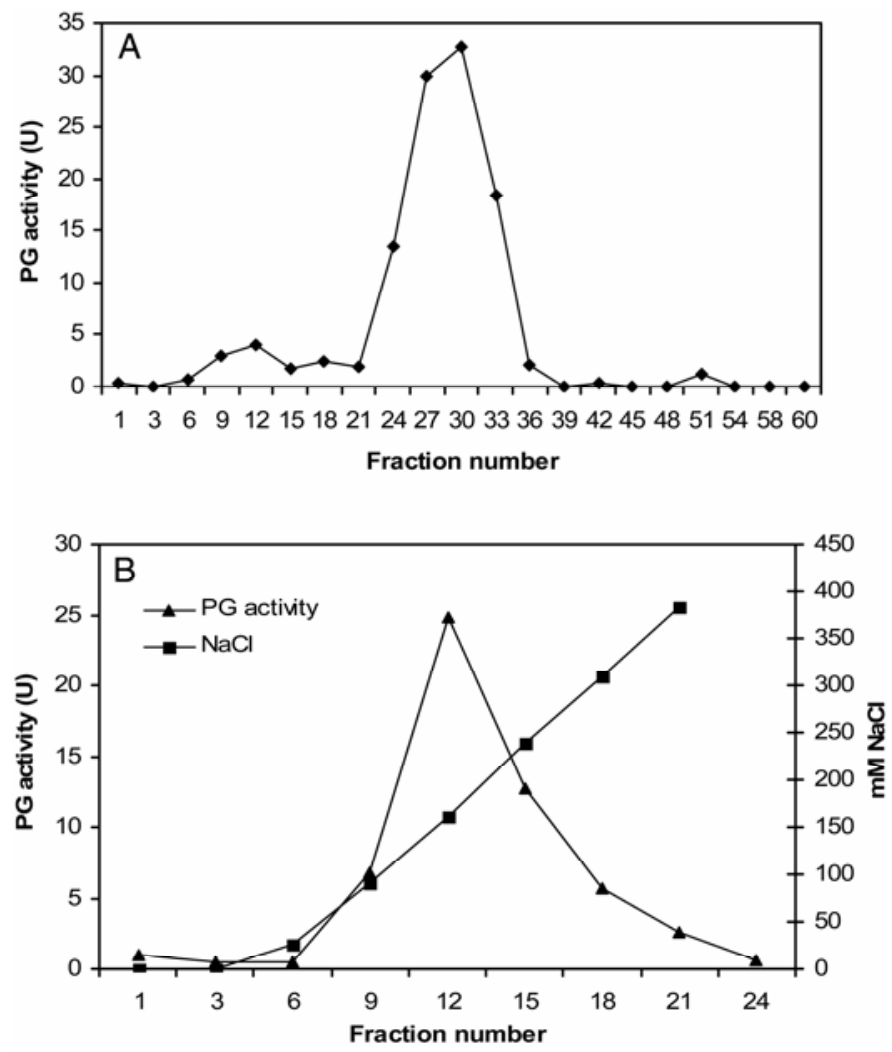

Fig. 1. A, Elution profile of a polygalacturonase (PG) sample produced by Penicillium solitum following fractionation on a Sephacryl S-200 gel filtration

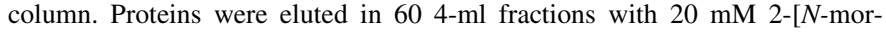
pholino]-ethanesulfonic acid (MES), pH 6.0. B, Elution profile of a pooled PG gel filtration peak on a CM-Sephadex cation exchange column. Proteins were eluted in 25 4-ml fractions with a 0 to $0.4 \mathrm{M}$ linear sodium chloride gradient in $20 \mathrm{mM}$ MES, pH 6.0. methanol:sulfuric acid [9:1, vol/vol]), The plate was then set on a hotplate at medium-high heat for $3 \mathrm{~min}$ to visualize the galacturonic acids as purple bands.

Apple maceration assay. Apple fruit were equilibrated at $20^{\circ} \mathrm{C}$ prior to the maceration assay. Sterile conditions were used throughout the procedure. An apple was rinsed with soap and water, dried with a paper towel, and sprayed with $95 \%$ ethanol. After the ethanol evaporated, a $4-\mathrm{cm}^{2}$ area of the fruit was peeled using a sterile scalpel. A cork borer ( $2 \mathrm{~mm}$ in diameter) was used to remove plugs of apple cortical tissue, which were then cut into $1-\mathrm{cm}$ pieces, weighed, and placed directly into $13 \times 100-\mathrm{mm}$ borosilicate tubes. Sets of three tubes containing the apple tissue were incubated with either 0.34 units of purified PG in $2 \mathrm{ml}$ of $100 \mathrm{mM}$ sodium acetate ( $\mathrm{pH} 5.5$ ), buffer only, or heat-denatured $\mathrm{PG}$ enzyme. After incubation at $20^{\circ} \mathrm{C}$ for $48 \mathrm{~h}$, the tissue samples were removed from the test tubes, blotted for $5 \mathrm{~s}$ on tissue paper, and weighed.

\section{RESULTS}

Purification of PG produced by $P$. soltium in decayed apple fruit. PG produced by $P$. solitum during apple fruit colonization was purified using a multistep process that involved ammonium sulfate, gel filtration, and cation exchange chromatography. Following each step, total protein and total activity decreased, whereas specific activity increased (Table 1). Single peaks, corresponding to PG activity, are shown for gel filtration and cation exchange chromatography (Fig. 1A and B). SDS-PAGE analysis of the cation exchange purified material revealed a single band of $\approx 50 \mathrm{kDa}$ (Fig. 2). The source of PG activity in $P$. solitum-apple fruit tissue is most likely to be fungal in origin as evidenced by the clear zone apparent from the $90 \%$ ammonium sulfate pellet collected from infected material and lack of a zone from both healthy and wounded $90 \%$ ammonium sulfate pellets (Fig. 3).

Biochemical characterization of $\boldsymbol{P}$. solitum PG. The $\mathrm{pH}$ optimum of purified PG was determined using buffers adjusted from $\mathrm{pH} 3$ to 7 with sodium polypectate in $100 \mathrm{mM}$ sodium acetate buffer as the substrate. The PG enzyme was active over a broad $\mathrm{pH}$ range of 3.5 to 7 with an optimum occurring at $\mathrm{pH} 4$ to 5 (Fig. 4). The heat stability of PG was examined by boiling aliquots of the enzyme for $0,5,10,15,20,25$, and $30 \mathrm{~s}$. The purified enzyme was heat sensitive because $\approx 50 \%$ of the activity

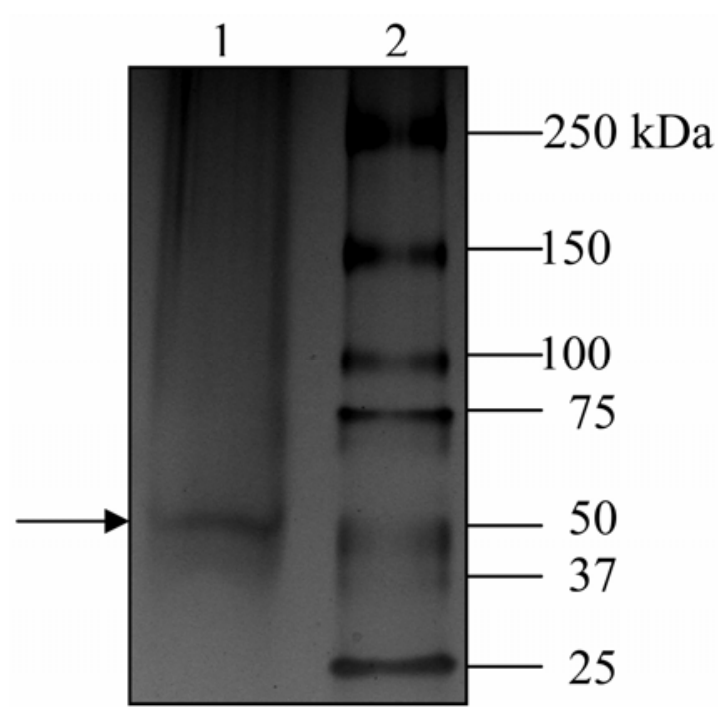

Fig. 2. Sodium dodecyl sulfate-polyacrylamide gel (4 to $20 \%$ gradient) electrophoresis that was treated with silver stain. Lane 1 contains $15 \mu \mathrm{l}$ of CM-Sephadex cation exchange-purified polygalacturonase from Penicillium solitum showing a single $50-\mathrm{kDa}$ band. Lane 2 contains $5 \mu \mathrm{l}$ of molecular weight marker. 
was destroyed when incubated for $10 \mathrm{~s}$ at $100^{\circ} \mathrm{C}$. No activity was detected following incubation in boiling water for $15 \mathrm{~s}$ (data not shown). The effect of temperature on purified PG enzyme activity was investigated by incubating the enzyme at 2, 20, 37, 50, and $75^{\circ} \mathrm{C}$ for $2 \mathrm{~h}$ and assaying the amount of reducing sugars liberated from sodium polypectate. PG activity was detectable at all temperatures examined. However, maximum activity was detected at 20 and $37^{\circ} \mathrm{C}$ (Fig. 5). The purified PG hydrolyzed polygalacturonic acid in a mixed manner exhibiting both endo and exo activity according to results from PG plate assay and TLC analysis (Figs. 6 and 7). The effect of various metal ions on purified PG activity was determined using sodium polypectate (Table 2). An increase in PG enzyme activity was observed with the addition of magnesium and iron whereas a decrease in activity occurred when calcium and manganese were included in the PG assay.

Maceration of apple fruit tissue in vitro. To quantitatively measure the maceration ability of purified PG, apple tissue plugs were incubated with buffer alone, heat-denatured PG, and native PG. After $24 \mathrm{~h}$, no change in the weight or visible deterioration of

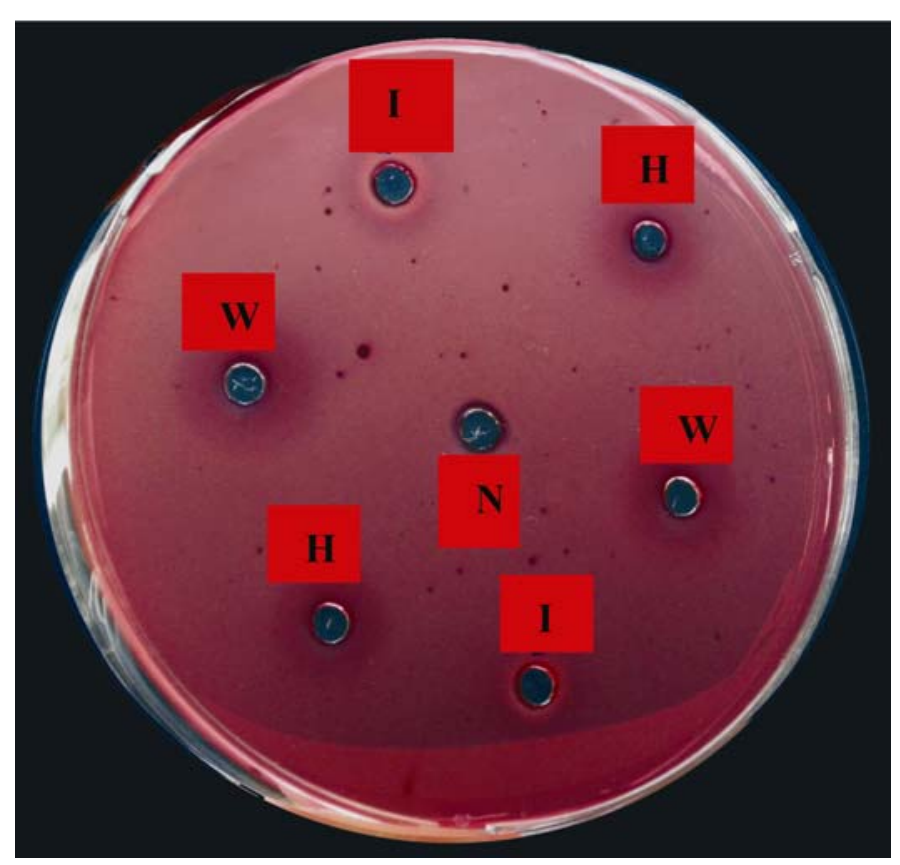

Fig. 3. Polygalacturonase plate assay of $90 \%$ ammonium sulfate pellets from $20 \mu \mathrm{g}$ of total protein of each healthy (H), wounded (W), and Penicillium solitum-decayed apple fruit tissue (I). Negative control (N) contained $5 \mu \mathrm{l}$ of $20 \mathrm{mM} 2$-[N-morpholino]-ethanesulfonic acid $+0.15 \mathrm{M}$ sodium chloride, $\mathrm{pH}$ 6.0. The experiment was repeated and a representative plate is shown.

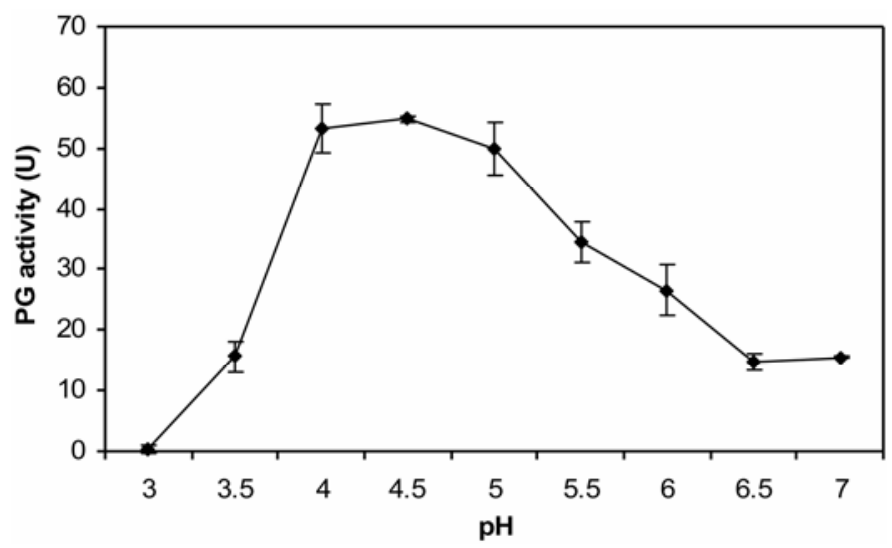

Fig. 4. Activity profile of purified polygalacturonase produced by Penicillium solitum in apple fruit at different $\mathrm{pHs}$. Each data point represents the mean and standard deviation of samples assayed in triplicate. apple disks was detectable (data not shown). However, a significant decrease in weight was observed after $48 \mathrm{~h}$ for tissue disks incubated with native PG compared with those incubated in buffer only or with denatured PG (Fig. 8). A significant change in texture and slight browning of the tissue was observed for the native PG-treated apple disks.

\section{DISCUSSION}

Gel filtration and cation exchange chromatography resulted in purification of PG produced by $P$. solitum to homogeneity. The molecular mass of the protein was estimated at $50 \mathrm{kDa}$, which is consistent with reports for other fungal PGs of 20 to $78 \mathrm{kDa}(20)$. For example, PG1 isolated from Phomopsis cucurbitae during

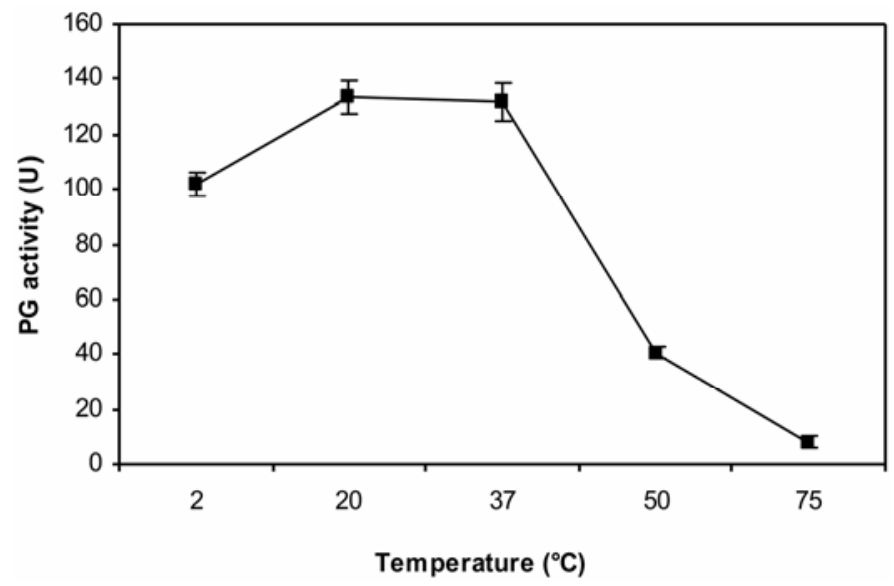

Fig. 5. Activity profile of purified polygalacturonase produced by Penicillium solitum in apple fruit at various temperatures. Each data point represents the mean and standard deviation of samples assayed in triplicate.

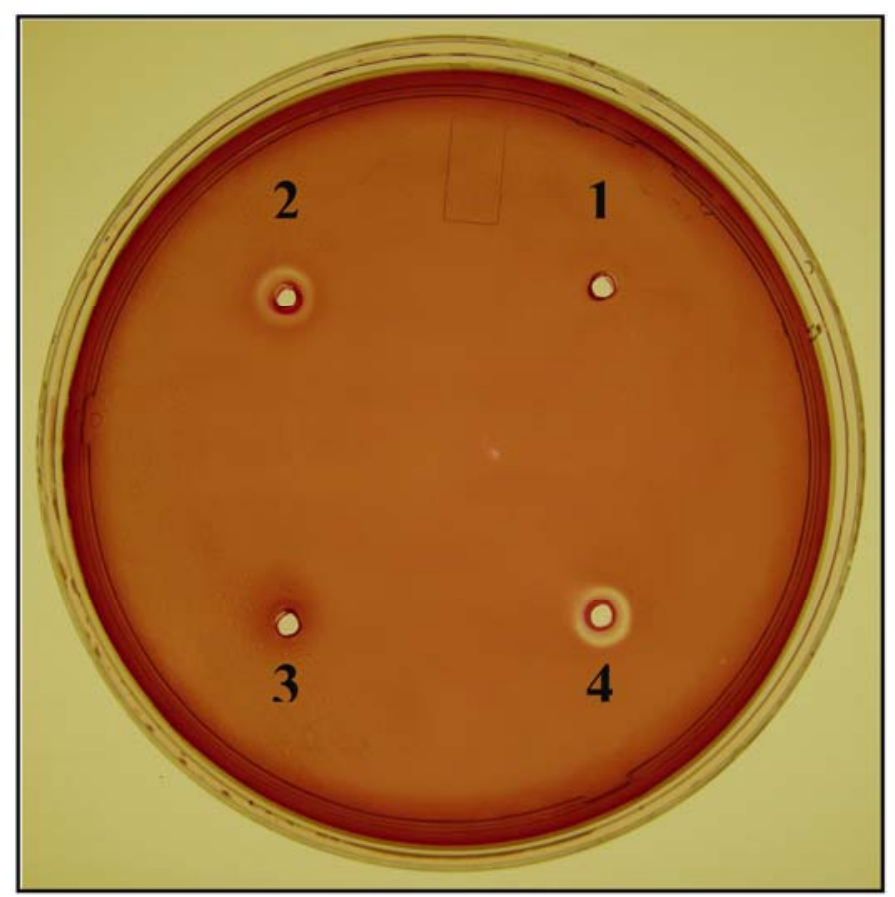

Fig. 6. Assay of polygalacturonase (PG) activity after staining $1 \%$ agarose plates containing $0.1 \%$ polygalacturonic acid with $0.05 \%$ ruthenium red solution. The wells were loaded with: $1,20 \mathrm{mM} 2$-[ $N$-morpholino]-ethanesulfonic acid in $0.15 \mathrm{M}$ sodium chloride $\mathrm{pH} 6.0 ; 2,5 \mathrm{U}$ of native Penicillium solitum PG from cation exchange; 3, $5 \mathrm{U}$ of denatured $P$. solitum PG from cation exchange; and 4, $5 \mathrm{U}$ of native $P$. expansum $\mathrm{PG}$ from cation exchange. Three plates were assayed together and the experiment was repeated. The results of one plate from a representative experiment are shown. 
decay of muskmelon was determined to be $54 \mathrm{kDa}$ (39). However, the PG produced by $P$. solitum is larger than the $34-\mathrm{kDa}$ enzyme that was isolated and characterized from $P$. expansum-decayed apple fruit (38).

The optimal PG activity at $\mathrm{pH} 4$ to 5 is consistent with data from other studies that have shown that $\mathrm{pH}$ optima for various fungal PGs are $\mathrm{pH} 3$ to $5(19,24,31)$. A narrow $\mathrm{pH}$ range of 4.5 to 6.5 with an optimum of 5.5 was determined for PG activity of $P$. expansum (38). A broader $\mathrm{pH}$ range of $\mathrm{PG}$ activity may provide $P$. solitum an ecological advantage because the fungus could utilize nutrients as a saprophyte while also being capable of degrading pectin from apple cell walls at a $\mathrm{pH}$ (3.95 to 4.54) that is common for apple fruit (23).

Temperature activity studies of the purified enzyme from $P$. solitum revealed that $\mathrm{PG}$ is active at temperatures as low as $2^{\circ} \mathrm{C}$. Activity at low temperature may facilitate host invasion and colonization during cold storage (35). Lack of $P$. solitum PG enzyme stability at $100^{\circ} \mathrm{C}$ contrasts with that reported for PG produced by $P$. expasum in decayed apple fruit (38). $P$. expansum $\mathrm{PG}$ activity was detectable following $15 \mathrm{~min}$ of incubation in boiling water whereas the $\mathrm{PG}$ purified from $P$. solitum was inactive following $15 \mathrm{~s}$ at $100^{\circ} \mathrm{C}$ (data not shown).

The increase in PG enzyme activity when $\mathrm{Mg}$ and Fe were added to the enzyme assay is in accord with an earlier report wherein $\mathrm{Mg}$ stimulated activity of a purified endoglucanase from the wood-decaying fungus Daldinia eschscholzii, which was

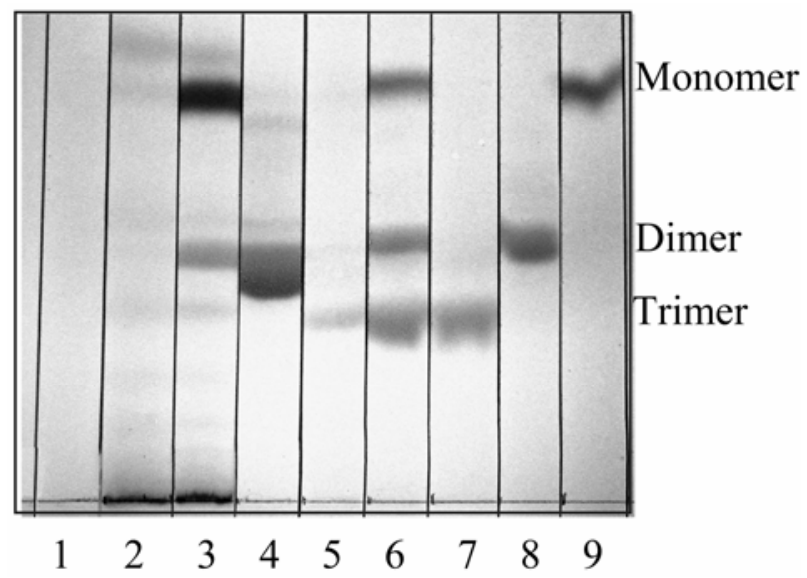

Fig. 7. Thin-layer chromatographic analysis of purified polygalacturonase (PG) reaction products with various polygalacturonic acid substrates. Standard assay buffer included $0.4 \%$ (wt/vol) Na polypectate. Lane 1, purified PG only; lane 2, standard assay buffer only; lane 3, $3.4 \mathrm{U}$ of purified PG in standard assay buffer; lane 4, $3.4 \mathrm{U}$ of purified PG in assay buffer containing polygalacturonic acid dimer; lane 5, $3.4 \mathrm{U}$ of purified PG in assay buffer containing polygalacturonic acid trimer; lane 6 , polygalacturonate monomer, dimer, and trimer standards; lane 7, polygalacturonate trimer; lane 8, polygalacturonate dimer; lane 9 , polygalacturonate monomer.

TABLE 2. Effect of divalent cations on purified polygalacturonase activity produced by Penicillium solitum

\begin{tabular}{lc}
\hline Compound $^{\mathrm{a}}$ & Percent relative activity (SD) \\
\hline Control & 100.0 \\
$\mathrm{CaCl}_{2}$ & $85.1(5.03)$ \\
$\mathrm{MgCl}_{2}$ & $111.0(2.51)$ \\
$\mathrm{MnSO}_{4}$ & $87.3(6.15)$ \\
$\mathrm{FeCl}_{2}$ & $130.0(5.34)$ \\
\hline
\end{tabular}

a Assays were carried out in the presence of $1 \mathrm{mM}$ concentration of each compound.

${ }^{b}$ Relative activity was determined by assaying polygalacturonase at $37^{\circ} \mathrm{C}$ in $100 \mathrm{mM} \mathrm{Na}$ acetate buffer $\mathrm{pH} 5.5$ for $2 \mathrm{~h}$. Mean values from samples assayed in duplicate are shown from a representative experiment. Standard deviation (SD) of the mean is shown in parentheses. hypothesized to be the result of stabilization of the overall enzyme structure (14). A decrease in PG activity was observed with the addition of $\mathrm{Ca}$ and $\mathrm{Mn}$, which have also been shown to inhibit other fungal PGs in vitro $(6,17,19)$. Several studies have shown that increased $\mathrm{Ca}$ in the fruit inhibits $P$. expansum-mediated decay of apple fruit after harvest (7-9). High Ca levels are thought to increase cell wall integrity by cross-linking pectic acids and thereby making pectin less accessible for breakdown by PG. However, it is not clear from data contained in this study how $\mathrm{Ca}$ decreases PG enzyme activity in vitro. Ca-mediated inhibition observed in vitro may be through binding of $\mathrm{Ca}$ to the polypectate in the enzyme assay buffer or binding to the purified PG enzyme and acting as a negative allosteric effector.

The purified PG hydrolyzed sodium polypectate in a mixed manner exhibiting both endo and exo activity. Mixed activity has also been reported for the purified PG from P. expansum (38). In the current study, the hydrolysis products were composed mostly of monomeric galacturonic acid but small amounts of digalacturonate and trigalacturonate were also detected in the enzyme reaction. Endo cleavage of polypectate was further substantiated by the PG plate assay because this class of hydrolase contributes more to the rapid reduction of the polypectate substrate (in $30 \mathrm{~min}$ ), thus yielding a clear zone because internal residues are cleaved on a random basis. The purified PG enzyme was unable to hydrolyze di- and trigalacturonic acid when they were included as a substrate in place of polypectate. This result suggests that the enzyme requires a minimum polymer length $>3$ residues for enzymatic cleavage. This is consistent with data from other fungal PGs exhibiting endo action because they also were unable to cleave dimers and trimers of galacturonic acid $(5,25)$.

A $30 \%$ reduction in mass resulted when apple tissue plugs were incubated with native PG from $P$. solitum. The reduction in mass represents the ability of the purified PG to degrade apple fruit tissue in vitro and substantiates the role of this enzyme in postharvest decay of apple fruit tissue by $P$. solitum. Interestingly, a $30 \%$ reduction in mass of muskmelon fruit plugs resulted from incubation with a purified PG from Phomopsis cucurbitae in vitro (39). The authors concluded that PG may be involved in Phomopsis fruit rot of muskmelon based on the ability of the enzyme to macerate muskmelon fruit tissue in vitro. Molecular genetic evidence has shown that $\mathrm{PG}$ is a virulence factor in both fungal and bacterial pathogens. Pseudomonas solanacerum and Agrobacterium tumefaciens biovar 3 mutants lacking PG genes were less virulent on their respective hosts $(26,29)$. Functional analysis of the Bcpg1 gene encoding an endopolygalacturonase in Botrytis cinerea showed that PG-null strains were less virulent on tomato

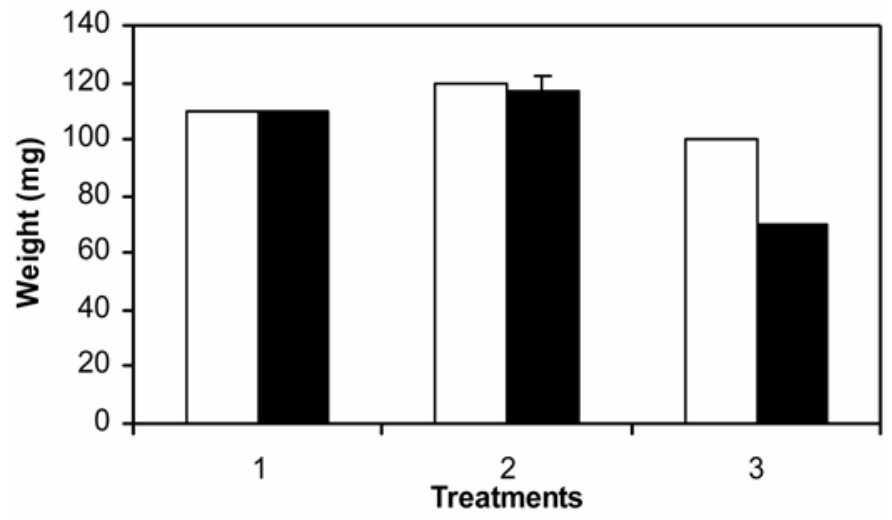

Fig. 8. Fresh weight changes in apple cortical tissue disks after different treatments: 1, $100 \mathrm{mM}$ sodium acetate buffer $(\mathrm{pH} 5.5)$; 2, heat-denatured Penicillium solitum polygalacturonase (PG) in buffer; and 3 , native $P$. solitum PG in buffer. Weight before treatment, white columns and weight after $48 \mathrm{~h}$, black columns. Vertical bars represent the means of treatments conducted in triplicate. Error bars represent the standard deviation of the mean. 
fruit and leaves and apple fruit compared with wild-type strains (11). A recent study of 10 PG genes from Phytophthora parasictica showed that each of the gene products plays a distinct role in decomposition of the plant cell wall (36).

The PG that was purified from $P$. solitum-decayed apple fruit was almost certainly produced by the fungus. This conclusion is based on the inability to detect PG activity from either wounded or intact apple fruit tissue in the plate assay after ammonium sulfate precipitation or fractionation. However, definitive proof will require sequence homology comparisons between the host (apple) and the pathogen (P. solitum) PG genes. Although such work is beyond the scope of this study, it will be considered in the future.

This is the first report on the isolation, purification, and biochemical characterization of PG from $P$. solitum-decayed tissue. This work provides a foundation for future genetic study of the role of PG in $P$. solitum-apple fruit interactions. The elucidation of its role by molecular cloning and functional analysis will provide further insight into the mechanisms of fungal invasion and colonization and will lead to the development of more specific and effective control strategies for postharvest fungal plant pathogens.

\section{ACKNOWLEDGMENTS}

This work was supported by the USDA CRIS project plan no. 127542430-008-00D. Mention of trade names or commercial products in the publication is solely for the purpose of providing specific information and does not imply recommendation or endorsement by the United States Department of Agriculture. We thank J. Norman Livsey and Verneta L. Gaskins for their technical contributions.

\section{LITERATURE CITED}

1. Annis, S. L., and Goodwin, P. H., 1997. Recent advances in the molecular genetics of plant cell wall degrading enzymes produced by plant pathogenic fungi. Eur. J. Plant Pathol. 103:1-14.

2. Bartley, I. M. 1977. Exo-polygalacturonase of apple. Phytochemistry 17:213-216.

3. Bateman, D. F., and Bashman, H. G. 1976. Degradation of plant cell walls and membranes by microbial enzymes. Encycl. Plant Physiol. New. Ser. 4:316-355.

4. Bateman, D. F., and Miller, R. L. 1966. Pectic enzymes in tissue degradation. Annu. Rev. Phytopathol. 4:119-146.

5. Bonnin, E., Le Goff, A., Korner, R., Vigouroux, J., Roepstorff, P., and Thibault, J. F. 2002. Hydrolysis of pectins with different degrees and patterns of methylation by the endopolygalaturonse of Fusarium moniliforme. Biochim. Biophys. Acta 1596:83-94.

6. Cabanne, C., and Doneche, B. 2002. Purification and characterization of two isozymes of polygalacturonase from Botrytis cinerea. Effect of calcium ions on polygalacturonase activity. Microbiol. Res. 157:183-189.

7. Conway, W. S. 1982. Effect of postharvest calcium treatment on decay of Golden Delicious apples. Plant Dis. 66:402-403.

8. Conway, W. S., Gross, K. C., and Sams, C. E. 1987. Relationship of bound calcium and inoculum concentration to the effect of postharvest calcium treatment on decay of apples by Penicillium expansum. Plant Dis. 71:78-80.

9. Conway, W. S., and Sams, C. E. 1983. Calcium infiltration of Golden Delicious apples and its effect on decay. Phytopathology 73:1068-1071.

10. Cooper, R. M., 1983. The mechanisms and significance of enzymic degradation of host cell walls by parasites. Pages 101-135 in: Biochemical Plant Pathology. J. A. Callow, ed. John Wiley \& Sons, New York.

11. Have, A. T., Mulder, W., Visser, J., and van Kan, J. A. L. 1998. The Endopolygalacturonase gene Bcpg1 for full virulence of Botrytis cinerea. Mol. Plant-Microbe Interact. 11:1009-1016.

12. Heldt, H. W., 1997. Plant Biochemistry \& Molecular Biology. Oxford University Press Inc., New York.

13. Jayani, R. S., Saxena, S., and Gupta, R. 2005. Microbial pectinolytic enzymes: a review. Process Biochem. 40:2931-2944.

14. Karnchanatat, A., Petsom, A., Sangvanich, P., Piapukiew, J., Whalley, A. J. S., Reynolds, C. D., Gadd, G. M., and Sihanonth, P. 2007. A novel thermostable endoglucanse from the wood-decaying fungus Daldinia eschscholzii (Ehrenb:Fr.) Rehm. Enzyme and Mircob. Tech. doi:10.1016/ j.enzmictec.2007.11.009.
15. Larsen, T. O., Lange, L., Schnorr, K., Stender, S., and Frisvad, J. C. 2007. Solistatinol, a novel phenolic compactin analogue from Penicillium solitum. Tetrahedron Lett. 48:1261-1264.

16. Leammli, U. K. 1970. Cleavage of structural proteins during the assembly of the head of bacteriophage T4. Nature 227:680-685.

17. Martins, E. S., Silva, D., Leite, R. S., and Gomes, E. 2007. Purification and characterization of polygalacturonase produced by thermophillic Thermoascus aurantiascus CBMAI-756 in submerged fermentation. Antonie Leeuwenhoek. 91:291-299.

18. McEvoy, J. L., Conway, W. S., and Janisiewicz, J. W. 2006. Virulence factors associated with Penicillium expansum and $P$. solitum during decay of apple fruit. (Abstr.) Phytopathology 96:S75.

19. Mohamed, S. A., Farid, N. M., Hossiny, E. N., and Bassuiny, R. I. 2006. Biochemical characterization of an extracellular polygalacturonase from Trichoderma harzianum. J. Biotechnol. 127:54-64.

20. Niture, S. K. 2008. Comparative biochemical and structural characterization of fungal polygalacturonases. Biologia 63:1-19.

21. Pilnik, W., and Voragen, A. G. J. 1991.The significance of endogenous and exogenous pectic enzyme in fruit and vegetable processing. Pages 330-336 in: Food Enzymology. P. F. Fox, ed. Elsevier Science Publishers, Amsterdam.

22. Pitt, J. I., Spotts, R. A., Holmes, R. J., and Cruickshank, R. H. 1991. Penicillium solitum revived, and its role as a pathogen of pomaceous fruit. Phytopathology 81:1108-1112.

23. Prusky, D. McEvoy, J. L., Saftner, R., Conway, W. S., and Jones, R. 2004. Relationship between host acidification and virulence of Penicillium spp. on apple and citrus fruit. Phytopathology 94:44-51.

24. Rao, M. N., Kembhavi, A. A., and Pant, A. 1996. Implication of tryptophan and histidine in the active site of endo-polygalacturonase from Aspergillus ustus: elucidation of the reaction mechanism. Biochim. Biophys. Acta 1296:167-173.

25. Rexova-Benkova, L., and Markovic, O. 1976. Pectic enzymes. Pages 323385 in: Advances in Carbohydrate Chemistry and Biochemistry. R. S. Tipson and D. Horton, eds. Academic Press, New York.

26. Rodriguez-Palenzuela, P., Burr, T. J., and Collmer, A. 1991. Polygalacturonase is a virulence factor in Agrobacterium tumefaciens biovar 3. J. Bacteriol. 173:6547-6552.

27. Rosenberger, D. A. 1990. Blue mold. Pages 54-55 in: Compendium of Apple and Pear Diseases. A. L. Jones and H. S. Aldwinkle, eds. The American Phytopathological Society, St. Paul, MN.

28. Saad, N., Briand, M., Gardarin, C., Briand, Y., and Michaud, P. 2007. Production, purification, and characterization of an endopolygalacturonase from Mucor rouxii NRRL 1894. Enzyme Microbiol. Technol. 41:800-805

29. Schell, M. A., Roberts, D. P., and Denny, T. P. 1988. Analysis of the Pseudomonas solanacearum polygalacturonase encoded by $p g l \mathrm{~A}$ and its involvement in phytopathogenicity. J. Bacteriol. 170:4501-4508.

30. Shieh, M. T., Brown, R. L., Whitehead, M. P., Cary, J. W., Cotty, P. J., Cleveland, T. E., and Dean, R. A., 1997. Molecular genetic evidence for the involvement of a specific polygalacturonase, $\mathrm{P} 2 \mathrm{c}$, in the invasion and spread of Aspergillus flavus in cotton bolls. Appl. Environ. Microbiol. 63:3548-3552.

31. Singh, S. A., and AppuRao, A. G. 1989. A simple fractionation protocol for and a comprehensive study of the molecular properties of two major endopolygalacturonases from Aspergillus niger. Biotechnol. Appl. Biochem. 35:115-123.

32. Smith, P. K., Krohn, R. I., Hermanson, G. T., Mallia, A. K., Gartner, F. H., Provenzano, M. D., Fujimoto, E. K., Goeke, N. M., Olson, B. J., and Klenk, D. C. 1985. Measurement of protein using bicinchoninic acid. Anal. Biochem. 150:76-85.

33. Sorensen, D., Larsen, T. O., Christophersen, C., Neilsen, P. H., and Anthoni, U. 1999. Solistatin, an aromatic compactin analogue from Penicillium solitum. Phytochemistry 51:1027-1029.

34. Walton, J. D. 1994. Deconstructing the cell wall. Plant Physiol. 104:11131118.

35. Watkins, C. B. 2003. Principles and practices of postharvest handling and stress. Pages 585-614 in: Apples: Botany, Production, and Uses. D. C. Ferree and I. J. Warrington, eds. CAB International, MA.

36. Wu, C. H., Yan, H. Z., Liu, L. F., and Liou, R. F. 2008. Functional characterization of a gene family encoding polygalacturonases in Phytophthora infestans. Mol. Plant-Microbe Interact. 21:480-489.

37. Wu, Q., Dobozi, M., Hemmat, M., and Hrazdina, G. 1993. Endopolygalacturonase in apples (Malus domsetica) and its expression during fruit ripening. Plant Physiol. 102:219-225.

38. Yao, C., Conway, W. S., and Sams, C. E. 1996. Purification and characterization of a polygalacturonase produced by Penicillium expansum in apple fruit. Phytopathology 86:1160-1166.

39. Zhang, J., Bruton, B. D., and Biles, C. L. 1999. Purification and chacterisation of a prominent polygalacturonase isozyme produced by Phomopsis cucrbitae in decayed muskmelon fruit. Mycol. Res. 103:21-27. 